\section{Root Zone Temperature, Plant Growth, and Fruit Yield of Tomatillo as Affected by Plastic Film Mulch}

\author{
Juan C. Díaz-Pérez, ${ }^{1}$ Sharad C. Phatak, ${ }^{2}$ David Giddings, ${ }^{3}$ and \\ Denne Bertrand ${ }^{3}$ \\ Department of Horticulture, Coastal Plain Experiment Station-Tifton Campus, \\ University of Georgia, Tifton, GA 31793-0748
}

\author{
Harry A. Mills ${ }^{2}$ \\ Department of Horticulture, University of Georgia, Athens, GA 30602
}

Additional index words. plasticulture, heat stress, husk tomato, Physalis ixocarpa, soil temperature, Solanaceae

\begin{abstract}
Tomatillo (Physalis ixocarpa Brot. ex Hornem) is a popular crop in Mexico and other Latin American countries. There is an increasing demand for this vegetable in the United States, particularly from the growing Latino population. However, there is limited information about tomatillo production. The objectives of this study were to determine the effects of plastic mulches on plant growth, yield, and root zone temperature in two cultivars of tomatillo. The study was conducted in Spring and Summer 2000. The design was a randomized complete block with a split plot arrangement, where plastic film mulch (black, gray, and silver mulches, and bare soil) was the main plot and cultivar ('Toma Verde' and 'Verde Puebla]) the subplot. In the spring, mulch treatments had little effect on plant growth during the first 30 days after transplanting and there were no significant differences in fruit yields. In the summer planting, both early growth and fruit yields were greatest with the silver and gray mulch treatments and lowest on bare soil. Plant growth during the establishment was related with subsequent plant growth and yield. In mature plants, vegetative top fresh weight and total fruit yield were higher $(P<0.01)$ in the spring than in the summer. Total fruit yield (both seasons), marketable yield (spring) and cull yield (spring) were lower in 'Toma Verde' than in 'Verde Puebla'. Root zone temperatures (RZTs) in the spring (mean $=26.4^{\circ} \mathrm{C}$ ) were lower than in the summer $\left(\right.$ mean $\left.=29.3^{\circ} \mathrm{C}\right)$. In both seasons, mean RZT was highest under black mulch and lowest in bare soil. In the summer, plant growth and fruit yields tended to decrease with increasing RZTs. Tomatillo plants grown on mulches with a mean seasonal $\mathrm{RZT}$ of $30^{\circ} \mathrm{C}$ had fruit yields that were $65 \%$ ('Toma Verde') or $50 \%$ ('Verde Puebla') lower respectively than those of plants on mulches with a RZT of $27^{\circ} \mathrm{C}$. There were no significant differences in foliar concentrations of $\mathrm{N}, \mathrm{Ca}, \mathrm{Mg}, \mathrm{S}, \mathrm{B}, \mathrm{Zn}, \mathrm{Cu}$ and $\mathrm{Na}$ among mulches. Foliar concentrations of the majority of mineral nutrients were not related with the mean RZT for the season.
\end{abstract}

Tomatillo (Physalis ixocarpa Brot. ex Hornem) or husk tomato is a solanaceous crop that originated in Mesoamerica and is popular in Mexico, Guatemala, and other Latin American countries (Montes-Hernández and AguirreRivera, 1994; Martínez, 1954; Waterfall, 1967). Tomatillo has been part of the diet of

Received for publication 14 Jan. 2005. Accepted for publication 20 Mar. 2005. I am graciously thankful to B. Mullinix for statistical assistance and to Melvin Hall, Patrick Conner, and Ron Robbins for reviewing the manuscript. Thanks also to E. Folds for secretarial support and to G. Acuña for help with field and laboratory tasks. We acknowledge support of the following donors: Rubén Araoz from Seminis for tomatillo seeds; United Irrigation and Roberts Irrigation Products Inc., for drip tape; Hydro Agri North America, Inc., for calcium nitrate liquid fertilizer; and Green-Tek and Sonoco for plastic film mulches. Mention of trade names in this publication does not imply endorsement by the University of Georgia of products named, nor criticism of similar ones not mentioned.

${ }^{1}$ Associate professor and corresponding author; e-mail jcdiaz@uga.edu.

${ }^{2}$ Professor.

${ }^{3}$ Research technician. the plant's growth habit. Wild tomatillo plants are often found growing in cultivated fields of tomato (Lycopersicon esculentum Mill.), corn (Zea mays L.) and cucurbits (Cucurbita spp.). Tomatillo plants require cross-pollination because of self-incompatibilty (Pandey, 1957). Tomatillo is a warm season crop, sensitive to freezing temperatures, and production of this crop in Mexico occurs in similar areas and growing seasons as those for tomato and pepper. There is no information on the optimum temperature for tomatillo growth, although plants grow poorly at $<16^{\circ} \mathrm{C}$, grow well at $>18$ ${ }^{\circ} \mathrm{C}$, and set fruit poorly at high temperatures (Smith et al., 1999).

In the southeastern United States, tomato and pepper (Capsicum annum L. var. annum) are commonly produced on plastic film mulch, while tomatillo has been grown in bare soil (Smith et al., 1999) or on plastic mulch (Freyre and Loy, 2000). The benefits associated with use of plastic mulches include higher yields, earlier harvests, improved weed control and increased efficiency in the use of water and fertilizers (Lamont, 1993). Plastic mulches affect plant microclimate by modifying the soil energy balance and restricting soil water evaporation (Liakatas et al., 1986; Tarara, 2000), thereby affecting plant growth and yield (Voorhees et al., 1981).

Root-zone temperature (RZT) is important in plant growth and development because it affects physiological processes in roots such as uptake of water and mineral nutrients (Cooper, 1973; Dodd et al., 2000; Tindall et al., 1990; Wien and Minotti, 1987). RZT may also be critical for plant survival, because roots have a lower temperature optimum and are less adapted to extreme fluctuations than shoots (Paulsen, 1994). Under controlled conditions, root growth increases nearly linearly with increased temperature from a minimum to an optimum temperature. Further increases in RZT are accompanied by a decline in root and shoot growth (Cooper, 1973; Miller, 1986; Voorhees et al., 1981). High RZT can have a drastic effect on plant growth, fruiting, water and mineral nutrient uptake, assimilate partitioning, and root respiration (Cooper, 1973; Dodd et al., 2000; Tindall et al., 1990; Tindall et al., 1991). The objectives of this study were to determine the effects of plastic mulches on RZT, plant growth, and fruit yield in two cultivars of tomatillo.

\section{Materials and Methods}

The study was conducted at the Coastal Plain Experiment Station, Tifton, Ga., during Spring and Summer 2000. The soil was a Tifton Sandy Loam (a fine loamy-siliceous, thermic Plinthic Kandiudults) with a $\mathrm{pH}$ of 6.5 . The design was a randomized complete block with three replications and a split plot arrangement, where plastic film mulch was the main plotand cultivar the subplot. The mulches were black on black (black), gray on black (gray, Leco, Montreal, Canada); silver on black (silver, Clarke Ag Plastics, Greenwood Va.), and bare soil. The cultivars were 'Toma Verde' and 'Verde Puebla' (both from Seminis, Oxnard, Calif.). 
The experimental plot consisted of a 7.6$\mathrm{m}$-long, 0.9-m-wide bed formed on 1.8-m centers. The soil was fumigated on $21 \mathrm{Feb}$. 2000 with a mixture of 3 methyl bromide : 1 chloropicrin (by weight) at $450 \mathrm{~kg} \cdot \mathrm{ha}^{-1}$. In the spring, before laying the mulches with a mulchlaying machine, the soil was fertilized with $\mathrm{N}$, $\mathrm{P}$, and $\mathrm{K}$ at 90,90 and $112 \mathrm{~kg} \cdot \mathrm{ha}^{-1}$, respectively. At the same time the mulches were laid, drip irrigation tape (T-Tape; T-Systems Intl., San Diego, Calif.), with 30.5-cm emitter spacing and a $17 \mathrm{~mL} \cdot \mathrm{min}^{-1}$ emitter flow, was placed 5 $\mathrm{cm}$ deep in the center of the bed.

In the spring, 4-week-old transplants were planted to the field on $5 \mathrm{Apr}$. and replanted on 5 May ('Toma Verde' only) in a single row per bed at $60-\mathrm{cm}$ spacing. In the summer, transplanting to the same field was on $12 \mathrm{Jul}$. 2000. After transplanting, $240 \mathrm{~mL}$ of starter fertilizer solution ( $555 \mathrm{ppm} \mathrm{N}$; $821 \mathrm{ppm} \mathrm{P;} 0$ ppm K) was applied directly to the base of each transplant. Three weeks after transplanting, plants were fertilized weekly through the drip system with $\mathrm{N}$ and $\mathrm{K}$ at rates of $1.5 \mathrm{~kg} \cdot \mathrm{ha}^{-1} \cdot \mathrm{d}^{-1}$ at early stages, $1.8 \mathrm{~kg} \cdot \mathrm{ha}^{-1} \cdot \mathrm{d}^{-1}$ during plant and fruit development, and $1.3 \mathrm{~kg} \cdot \mathrm{ha}^{-1} \cdot \mathrm{d}^{-1}$ at late stages of plant development. The total amount for each, $\mathrm{N}$ and $\mathrm{K}$ received by the plants after transplanting was $113 \mathrm{~kg} \cdot \mathrm{ha}^{-1}$.

Irrigation and soil water potential. Drip irrigation was applied as necessary to maintain soil water potential at more than $-15 \mathrm{kPa}$. Plants were typically irrigated $13 \mathrm{~mm}$ of water 3 to 4 times a week. Soil water potential (SWP) was monitored manually with granular matrix sensors (model 200SS; Water Mark soil moisture sensor, Irrometer Co., Riverside, Calif.) at 0.15 $\mathrm{m}$ deep, located midway between two plants within the row.

Root-zonetemperature. RZT was measured by determining soil temperature midway between the plants at $10 \mathrm{~cm}$ below the mulch and the soil surface. RZT over the growing season was measured with copper-constantan thermocouples (model 107; Campbell Scientific, Logan, Utah) connected to a datalogger (CR10X; Campbell Scientific) and a relay multiplexer (AM416; Campbell Scientific). The data logger was programmed to record readings every $10 \mathrm{~min}$ and store hourly averages for each plot. Air temperature data were obtained from a University of Georgia weather station located within $3 \mathrm{~km}$ of the plots.

Soil and foliar nutrients. Soil and leaf samples were collected on 29 Aug. 2000 (summer season). Leaves were dried at 70 ${ }^{\circ} \mathrm{C}$ for $2 \mathrm{~d}$ and analyzed for mineral nutrient concentration. Concentrations of $\mathrm{P}, \mathrm{K}, \mathrm{Ca}$, $\mathrm{Mg}, \mathrm{Fe}, \mathrm{Mn}, \mathrm{Zn}$, and $\mathrm{Cu}$ were determined by atomic absorption spectrophotometry. Tissue $\mathrm{N}$ concentration was determined by the copper catalyst method (Association of Official Analytical Chemists, 1990).

Plant growth. On days 7, 14, 21, and 28 after transplanting, two randomly-selected plants (top plus roots) from each replication were removed from the soil. Plant tops and roots were dried at $70^{\circ} \mathrm{C}$ and their dry weights (DWs) were determined.

Harvest. For the spring crop, a once-over harvest was made on 21 June, and the summer crop was harvested on 8 Sept. and 27 Sept. Only total yield data for the summer are reported. At the once-over harvest or at the last harvest, plants were excised at the soil level, enclosed individually in plastic bags and kept at $10^{\circ} \mathrm{C}$ until their vegetative fresh weight $(\mathrm{FW})$ and fruit yield (including both developing and fully developed fruit) were determined within $24 \mathrm{~h}$. A fruit is considered ripe when the berry fills the husk and in some cases breaks it (Moriconi et al., 1990). Fruit were graded as marketable


Fig. 1. Vegetative top dry weight of tomatillo plants grown on plastic mulches during the establishment period in the spring and the summer. Within the same day after transplanting, values with different letter are significantly different $(P \leq 0.05 ; \mathrm{n}=3$ replications, number of plants $=4)$. 


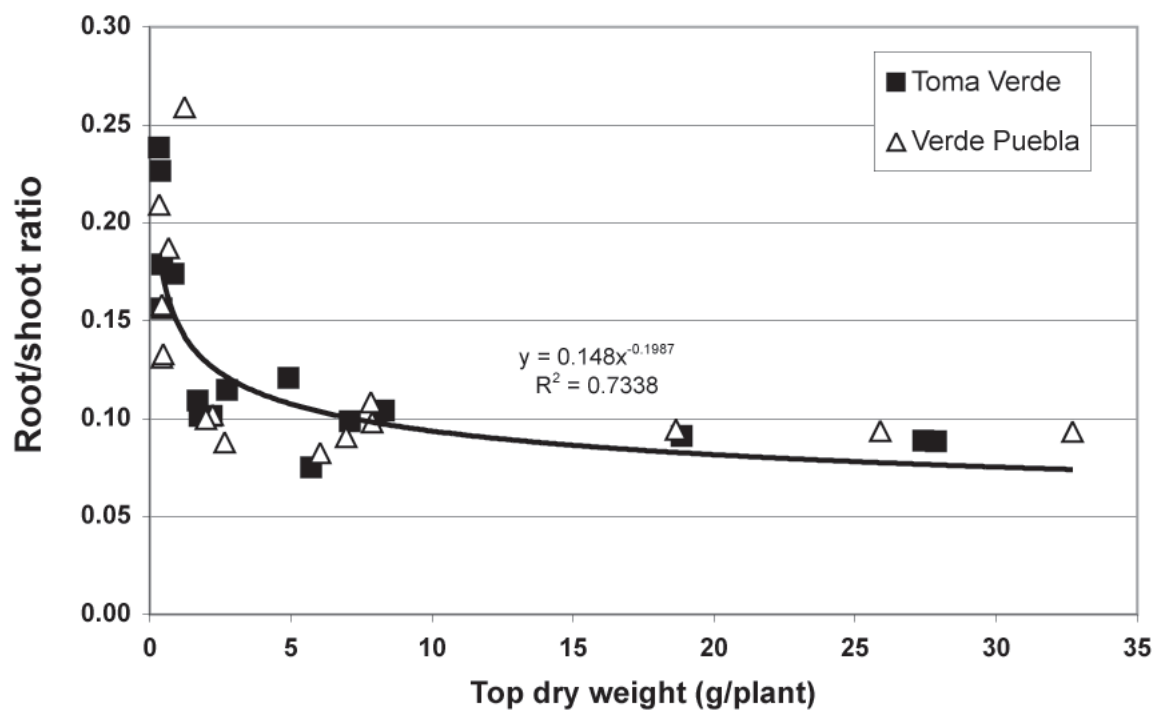

Fig. 2. Changes in root to top ratio of tomatillo plants during the establishment. Solid line was fit by linear regression.

Table 1. Growth and yield of tomatillo plants as affected by cultivar and plastic film mulch during the spring season.

\begin{tabular}{|c|c|c|c|c|c|}
\hline Treatment & $\begin{array}{c}\text { Vegetative } \\
\text { fresh wt } \\
\text { (kg/plant) }\end{array}$ & $\begin{array}{c}\text { Total } \\
\text { fruit } \\
\text { yield } \\
\text { (kg/plant) }\end{array}$ & $\begin{array}{c}\text { Marketable } \\
\text { yield } \\
\text { (kg/plant) }\end{array}$ & $\begin{array}{c}\text { Cull } \\
\text { yield } \\
\text { (kg/plant) }\end{array}$ & $\begin{array}{c}\text { Harvest } \\
\text { ratio }\end{array}$ \\
\hline \multicolumn{6}{|l|}{ Cultivar } \\
\hline Toma Verde & $2.2 \mathrm{~b}^{\mathrm{z}}$ & $1.1 \mathrm{~b}$ & $1.1 \mathrm{~b}$ & $0.01 \mathrm{~b}$ & 0.33 \\
\hline Verde Puebla & $2.7 \mathrm{a}$ & $1.9 \mathrm{a}$ & $1.6 \mathrm{a}$ & $0.3 \mathrm{a}$ & 0.41 \\
\hline \multicolumn{6}{|l|}{ Mulch } \\
\hline Bare & $2.0 \mathrm{~b}$ & 1.5 & 1.4 & 0.1 & 0.42 \\
\hline Black & $2.5 \mathrm{a}$ & 1.4 & 1.2 & 0.2 & 0.35 \\
\hline Gray & $2.8 \mathrm{a}$ & 1.6 & 1.5 & 0.1 & 0.35 \\
\hline Silver & $2.6 \mathrm{a}$ & 1.4 & 1.2 & 0.2 & 0.35 \\
\hline
\end{tabular}

${ }^{\mathrm{z}}$ Means separated within columns by Fisher's protected LSD test $(P \leq 0.05)$.

Table 2. Growth of mature plants, yield and soil water potential of tomatillo plants as affected by cultivar and plastic film mulch during the summer season.

\begin{tabular}{lccc}
\hline & $\begin{array}{c}\text { Total } \\
\text { Vegetative } \\
\text { fresh wt } \\
\text { (kg/plant) }\end{array}$ & $\begin{array}{c}\text { fruit } \\
\text { yield } \\
(\mathrm{kg} / \text { plant })\end{array}$ & $\begin{array}{c}\text { Harvest } \\
\text { ratio }\end{array}$ \\
\hline Creatment & & & \\
Toltivar & & & \\
Toma Verde & $2.2 \mathrm{a}^{\mathrm{z}}$ & $0.8 \mathrm{~b}$ & $0.25 \mathrm{~b}$ \\
Verde Puebla & $1.9 \mathrm{~b}$ & $1.2 \mathrm{a}$ & $0.39 \mathrm{a}$ \\
Mulch & & & \\
Bare & $1.2 \mathrm{~b}$ & $0.5 \mathrm{~b}$ & 0.27 \\
Black & $2.4 \mathrm{a}$ & $0.9 \mathrm{ab}$ & 0.28 \\
Gray & $2.5 \mathrm{a}$ & $1.3 \mathrm{a}$ & 0.34 \\
Silver & $2.2 \mathrm{a}$ & $1.3 \mathrm{a}$ & 0.36 \\
\hline
\end{tabular}

${ }^{\text {zMeans separated within columns by Fisher's pro- }}$ tected LSD test $(P \leq 0.05)$.

for RZT, plant growth attributes and fruit yields were separated by the Fisher's protected LSD test. Relationships of plant growth attributes with RZT were constructed using the means of the interaction of season, mulch and cultivar. Various models were evaluated to determine whether there were differences in the relationship of plant growth and yield to RZT among seasons and mulch types.

\section{Results and Discussion}

Effect of mulch and cultivar on plant growth
Mexico, tomatillo yields range from 15 th ha to $25 \mathrm{t} \cdot \mathrm{ha}^{-1}$, while in a Louisiana trial yield was $13.5 \mathrm{t} \cdot \mathrm{ha}^{-1}$ (Moriconi et al., 1990). Thus, yields in this study were low but acceptable in the spring and unacceptably low in the summer. Yields were low in part because plants were harvested only once in the spring or twice in the summer, while under typical growing conditions tomatillo is harvested four to six times (Moriconi et al., 1990).

Vegetative FWs and total fruit yields among mulches and between cultivars are presented in Tables 1 and 2. 'Toma Verde' vegetative FW growth in the spring was less than that of 'Verde Puebla' (Table 1), but the growing season was only $47 \mathrm{~d}$ for 'Toma Verde', compared to $77 \mathrm{~d}$ for 'Verde Puebla'. In the summer the growing season was the same for both cultivars, and vegetative FW growth of 'Toma Verde' was significantly greater than that of 'Verde Puebla' (Table 2). Total fruit yield (both seasons), marketable yield (spring) and cull yield (spring) were lower in 'Toma Verde' than in 'Verde Puebla'. Average fruit weight was higher in 'Verde Puebla' $(17.1 \mathrm{~g})$ compared to that in 'Toma Verde' (11.8 g). In the spring, harvest ratio (HR) tended to be higher in 'Verde Puebla' (Table 1), and in the summer HR was higher in 'Verde Puebla' than in 'Toma Verde' (Table 2).

In both seasons, plants on bare soil had the lowest vegetative FW and there were no differences in vegetative $\mathrm{FW}$ among the three plastic mulch treatments (Tables 1 and 2). In the spring there were no differences in total fruit yields among bare soil and mulch treatments (Table 1), while in the summer fruit yield was lowest with the bare soil treatment and highest with the gray and silver mulch treatments. Fruit yield was intermediate with the black mulch treatment, but not statistically different from the other treatments (Table 2). Harvest ratios were similar among mulch treatments in both seasons. Mean soil water potential was maintained at more than $-18 \mathrm{kPa}$ for all mulch treatments (Table 2), thus, soil moisture was probably not a major factor determining the differences in vegetative FW and fruit yield among mulch treatments.

Plant growth during the establishment period may significantly affect subsequent plant growth and fruit yield, as shown for tomato (Díaz-Pérez et al, 2004). In the spring, top DW during the establishment was not related with subsequent growth (vegetative top FW) and yield of mature plants. In the summer, vegetative top FW of mature plants of both cultivars was linearly related with top DW during the establishment (Fig. 3). Fruit yields of both cultivars were also linearly related with top DW during the establishment in the summer, although yields in 'Verde Puebla' were more affected than 'Toma Verde' by changes in the top DW during the first 28 DAT.

Effect of plastic mulch on root zone temperature. Plastic film mulches differed in their soil-warming ability. For all mulch treatments, root zone temperatures (RZTs) in the spring (average $=26.4^{\circ} \mathrm{C}$ ) were lower than in the summer (average $\left.=29.3{ }^{\circ} \mathrm{C}\right)$ (Table 3, Figs. 4 and $5)$. As the season progressed, RZTs increased 

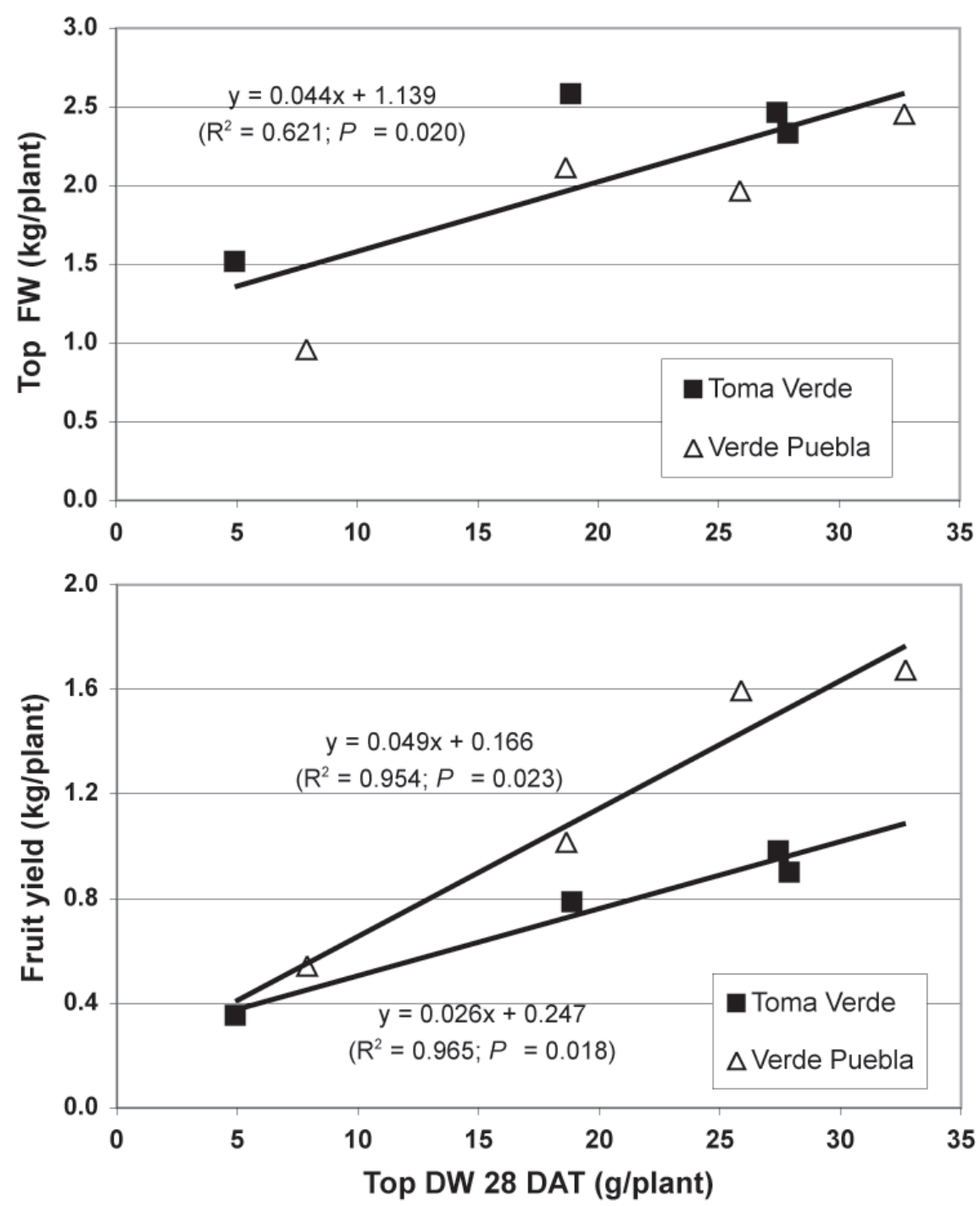

Fig. 3. Relationship of vegetative growth of mature plants and fruit yield with plant growth during the establishment period in two tomatillo cultivars. Solid lines were fit by linear regression.

linearly $(P<0.01)$ with time after transplanting in the spring and decreased linearly $(P<$ 0.01 ) in the summer (Fig. 4). Changes in mean daily RZTs under mulch were proportional $(P$ $<0.01)$ to changes in air temperature through both of the seasons. Over the two seasons, the mean air temperature $\left[22.3^{\circ} \mathrm{C}\right.$ (spring) and 25.6 ${ }^{\circ} \mathrm{C}$ (summer)] was lower than mean RZTs in either bare soil or under the plastic mulches. The differences between the daily mean air temperature and the daily mean RZTs under the mulch treatments tended to decrease with time as both seasons progressed.

In both seasons, mean RZT was highest under black mulch and lowest in bare soil. Maximal RZT was highest under black mulch in both seasons and lowest under silver mulch and gray mulch (only in the summer). In both seasons, lowest values of minimal RZT occurred in bare soil, and there were no consistent differences in minimal RZT among plastic mulches (Table 3). The largest RZT range (highest daily mean RZT -lowest daily mean RZT $=2.0^{\circ} \mathrm{C}$ ) among mulches occurred within the first 35 (spring) or 42 (summer) d after transplanting between maximal RZT and minimal RZT (9.9 ${ }^{\circ} \mathrm{C}$ in the spring and $9.6{ }^{\circ} \mathrm{C}$ in the summer)] compared to any of the mulch treatments (Fig. 5). Among mulch treatments, silver mulch had the smallest diurnal fluctuation in RZT $\left(6.2{ }^{\circ} \mathrm{C}\right.$ in the spring and $6.9^{\circ} \mathrm{C}$ in the summer). These diurnal responses of mulches are consistent with previous reports (Díaz and Batal, 2002).

Relationship of RZT with plant growth and yield. During the establishment period (first 28 $\mathrm{d}$ after transplanting), plant growth (top DW) in the spring increased with increases in the mean RZT (as affected by plastic mulches), while in the summer top DW decreased with increases in the mean RZT during the establishment (Fig. 6). Subsequent plant growth (vegetative $\mathrm{FW}$ ) was not significantly related to RZT, although vegetative FW tended to decrease with increasing values of RZT. Total fruit yield in 'Toma Verde' decreased with increasing values of both maximal RZT and mean RZT, while in 'Verde Puebla', total fruit yield increased with increasing RZTs to an 'optimum' RZT and then decreased at RZTs above the optimum (Fig. 7). Quadratic equations were used to compute optimum RZTs for plant growth during the establishment and for total fruit yield of cultivar Verde Puebla. The optimum RZTs were calculated by setting the first derivative of the equations equal to 0 . The predicted optimum mean RZTs for plant growth during the establishment and fruit yield were $27.7^{\circ} \mathrm{C}\left(\mathrm{y}=-0.600 \mathrm{x}^{2}+33.27 \mathrm{x}-430.5 ; r^{2}=\right.$ $0.861)$ and $27.3{ }^{\circ} \mathrm{C}$, respectively.

The effect of RZT on fruit yield, however, was more marked in the summer, when RZTs were higher, than in the spring. Possibly, yields in the spring were higher than in the summer because of presence of more favorable air temperatures and RZTs in the spring (mean RZT $=26.4{ }^{\circ} \mathrm{C}$ ) than in the summer (mean RZT $=$ $29.3{ }^{\circ} \mathrm{C}$ ). The high RZTs under black mulch in the afternoon are probably associated with the major detrimental effect of this mulch on the growth and yield of tomatillo during the summer. In southern Georgia, tomato yields in the spring are typically higher than in the summer and fall in part because excessively high air temperatures and high RZTs in the summer/fall reduce tomato plant growth and yield (Díaz-Pérez and Batal, 2002). In addition to RZT, other environmental factors such as daylength and amount of solar radiation that plants received may have also had an effect on tomatillo yields, as has been reported for tomato (Kinet and Peet, 1997). Insect and disease pressures in southern Georgia are also usually higher in the summer/fall than in the spring season.

Plant growth in tomato and other crops has been found to fit a quadratic relationship with RZT (Cooper, 1973; Díaz-Pérez and Batal, 2002). Optimal mean seasonal RZT for tomato growth and fruit yield is $26.3^{\circ} \mathrm{C}$ (Díaz-Pérez and Batal, 2002). In the current study, we found a quadratic relationship with RZT for fruit yield in 'Verde Puebla', with an optimal at $27.3^{\circ} \mathrm{C}$. Fruit yield of 'Toma Verde' did not have a significant quadratic relationship with RZT, instead yield decreased linearly 

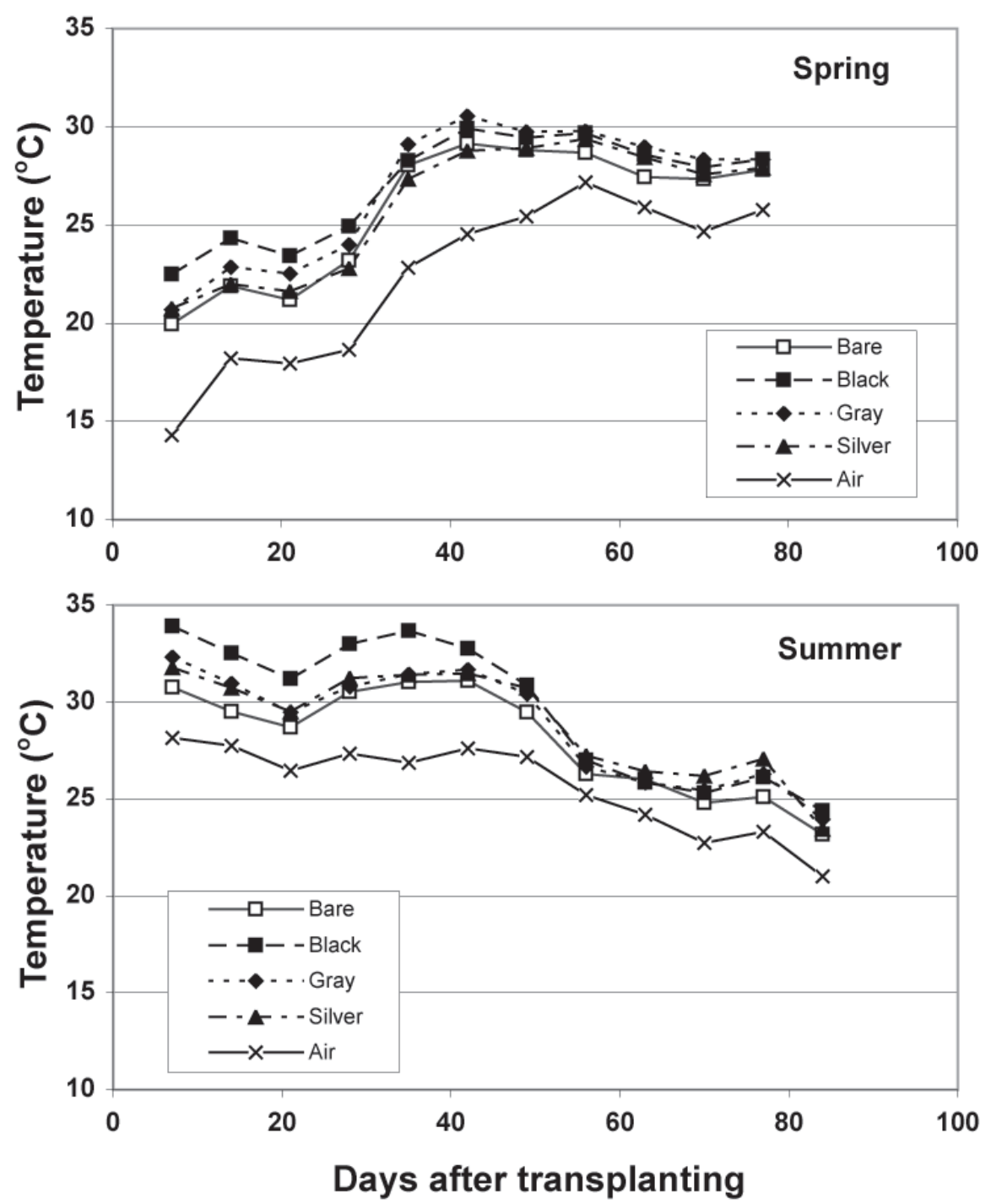

Fig. 4. Seasonal trend of root zone temperature (RZT) and air temperatures under plastic mulches during two seasons. Each symbol represents the weekly mean RZT under each mulch.

with increasing mean RZTs. Fruit yield on bare soil during the summer was lower than with any of the mulches and did not fit into the same relationship, suggesting that yield of plants on bare soil was affected more by factors other than RZT.

Tomatillo plants grown on mulches with a mean seasonal RZT of $30{ }^{\circ} \mathrm{C}$ had fruit yields that were $65 \%$ ('Toma Verde') and $50 \%$ ('Verde Puebla') lower respectively than those of plants on mulches with a mean RZT of 27 ${ }^{\circ} \mathrm{C}$. These results suggest that tomatillo may be more tolerant to heat stress than tomato, since yields are nil when tomato plants are grown at a mean seasonal RZT of $\geq 29.3{ }^{\circ} \mathrm{C}$ (Díaz-Pérez and Batal, 2002).

Fruit yield was consistently higher in 'Verde Puebla' than in 'Toma Verde' over the RZT ranges (Fig. 7), although as mean RZT increased above $27^{\circ} \mathrm{C}$, yield differences between cultivars tended to be smaller. Harvest ratios (HRs) tended to decrease with increasing values of mean RZT $\left[\mathrm{y}=-0.0272 \mathrm{x}+1.047, r^{2}=\right.$ $0.439, P=0.073$ ('Toma Verde'); $\mathrm{y}=-0.0113 \mathrm{x}$ $+0.713, r^{2}=0.199, P=0.268$ ('Verde Puebla')] and maximal RZT $\left[\mathrm{y}=-0.0047 \mathrm{x}^{2}+0.279 \mathrm{x}\right.$
$-3.846, r^{2}=0.492, P=0.184$ ('Toma Verde'); $\mathrm{y}=-0.0064 \mathrm{x}^{2}+0.405 \mathrm{x}-5.937, r^{2}=0.657$, $P=0.069$ ('Verde Puebla')]. The decrease in HR with increases in RZT was possibly due to the stronger effect of high RZTs on fruit yield than on vegetative FW. Similarly, RZTs above the optimal range in tomato result in plants with a decreased HR (Díaz-Pérez and Batal, 2002).

In tomato, high RZTs are more deleterious to fruit yield than to vegetative growth, and the effect of heat stress is primarily by reducing the number of fruit per plant (Díaz-Pérez and Batal, 2002). In pepper and tomato, high air temperatures $\left(>32^{\circ} \mathrm{C}\right)$ can drastically affect pollination and fruit set (Kinet and Peet, 1997; Wien, 1990). Presence of high air temperatures are expected to be associated with high RZTs, as shown by the relationship of RZT with air temperature among mulches $(P<0.01)$. In several agronomic crops, root temperature stress has been found to influence anthesis and seed development (Zobel, 1992). High RZTs can have a strong effect on vegetative growth, water and mineral nutrient uptake, assimilate partitioning and root respiration (Cooper,
1973; Dodd et al., 2000; Tindall et al., 1990). Plant organs may differ in their sensitivity to RZT, as in greenhouse-grown tomato where the optimal RZT for shoot dry matter production is $24{ }^{\circ} \mathrm{C}$ and that for roots is $26^{\circ} \mathrm{C}$. In the present study there were differences in thermal sensitivity among tomatillo cultivars, which is not surprising because tomatillo cultivars are highly variable genetically (Montes-Hernández and Aguirre-Rivera, 1994). Our results on the effect of RZT on tomatillo yield, however, cannot be conclusive since they are based on relatively few data points [ 8 (four mulches $\times$ two seasons)] over a limited temperature range (seasonal mean RZT $=25.8-30.2^{\circ} \mathrm{C}$ ).

Root zone temperature as affected by mulches can have a major impact on plant growth and yield but under certain conditions, other factors such as high insect pressure, may be more important. In both seasons, there was a higher incidence of silverleaf whiteflies (Bemisia argentifolii Bellows \& Perring) and western flower thrips (Frankliniella occidentallis Pergande) in plants grown in bare-soil relative to those on plastic mulch (Díaz-Pérez, personal observation), which possibly explains the reduced yields of plants grown in bare soil. Thus, from the thermal point of view, bare soil may be a better option than black mulch during high-temperature conditions. However, bare soil may result in increased incidence of insects. In addition, colored mulches have been shown to affect plant growth and yield by modifying insect behavior (Schalk and Robbins, 1987).

Incidence of TSWV. Presence ofTSWV was observed in the spring but not in the summer season. Incidence of TSWV $($ mean $=5.7 \%)$ was not affected $(P \leq 0.05)$ by plastic mulches or cultivars, and it was not related with mean seasonal RZT. The infection of TSWV in symptomatic plants was confirmed by enzymelinked-immunosorbent assay (ELISA), using a commercially available kit (Agdia Inc., Elkhart, Ind.). Preliminary results of this study were documented previously (Díaz-Pérez and Pappu, 2000).

Mineral nutrient concentration in the soil and leaf (summer season). Concentrations of $\mathrm{P}, \mathrm{Mn}$, and $\mathrm{Fe}$ in bare soil were the lowest, while concentrations of $\mathrm{K}, \mathrm{B}$, and $\mathrm{Zn}$ in bare soil were among the highest (Table 4 ). There were no differences in soil nutrient concentrations among plastic mulches, except for black mulch which had the highest $\mathrm{B}$ concentration and silver mulch which had among the lowest $\mathrm{K}$ and $\mathrm{Zn}$ concentrations. There were no differences in concentrations of soil mineral nutrient between cultivars.

Foliar concentrations of $\mathrm{P}$ and $\mathrm{K}$ were among the highest in bare soil and among the lowest in gray mulch (Table 5). Foliar concentration of Mn was among the lowest in silver mulch, while that of Mo was highest in bare soil. There were no significant differences in foliar concentrations of $\mathrm{N}, \mathrm{Ca}, \mathrm{Mg}, \mathrm{S}, \mathrm{B}, \mathrm{Zn}$, $\mathrm{Cu}$, and $\mathrm{Na}$ among mulch treatments. Except for the higher concentration of $\mathrm{Na}$ in 'Verde Puebla' than in 'Toma Verde', foliar concentrations of mineral nutrients were similar between cultivars. Foliar concentrations of the 

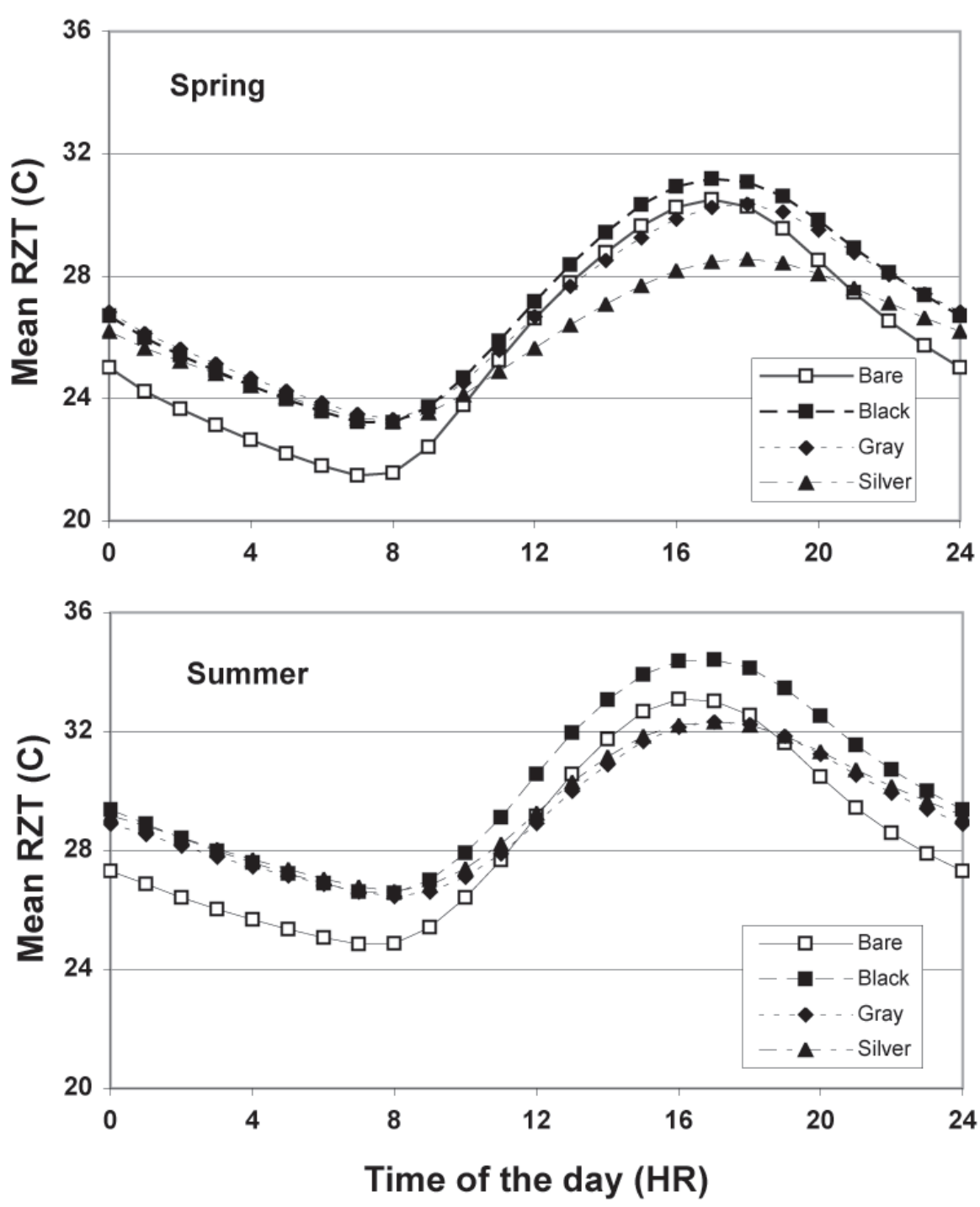

Fig. 5. Diurnal trends in root zone temperature (RZT) under plastic mulches during two growing seasons. Each symbol represents the hourly mean RZT for the entire season.

Table 3. Seasonal root zone temperature (RZT) of tomatillo plants in the spring and summer seasons as affected by plastic film mulch.

\begin{tabular}{llll}
\hline & $\begin{array}{l}\text { Mean } \\
\text { RZT } \\
\left({ }^{\circ} \mathrm{C}\right)\end{array}$ & $\begin{array}{l}\text { Max. } \\
\text { RZT } \\
\left({ }^{\circ} \mathrm{C}\right)\end{array}$ & $\begin{array}{l}\text { Min. } \\
\text { RZT } \\
\left({ }^{\circ} \mathrm{C}\right)\end{array}$ \\
\hline Spring & & & \\
$\quad$ Bare soil & $25.8 \mathrm{~d}^{\mathrm{z}, \mathrm{y}}$ & $31.2 \mathrm{~b}$ & $21.3 \mathrm{c}$ \\
Black & $27.0 \mathrm{a}$ & $31.7 \mathrm{a}$ & $23.0 \mathrm{~b}$ \\
Gray & $26.8 \mathrm{~b}$ & $30.8 \mathrm{~b}$ & $23.2 \mathrm{a}$ \\
$\quad$ Silver & $26.0 \mathrm{c}$ & $29.1 \mathrm{c}$ & $22.9 \mathrm{~b}$ \\
Summer & & & \\
Bare soil & $28.4 \mathrm{c}$ & $34.2 \mathrm{~b}$ & $24.6 \mathrm{~b}$ \\
Black & $30.2 \mathrm{a}$ & $35.4 \mathrm{a}$ & $26.3 \mathrm{a}$ \\
Gray & $29.2 \mathrm{~b}$ & $33.2 \mathrm{c}$ & $26.3 \mathrm{a}$ \\
Silver & $29.4 \mathrm{~b}$ & $33.2 \mathrm{c}$ & $26.3 \mathrm{a}$ \\
\hline
\end{tabular}

${ }^{\mathrm{z}}$ Means separated within columns and season by Fisher's protected LSD test $(P \leq 0.05)$.

'Values represent the seasonal average of daily values of mean, maximum or minimum root zone temperature for each of the plastic mulches.

majority of mineral nutrients were not related with the mean RZT for the season, except for the concentrations of $\mathrm{P}, \mathrm{Zn}$ and $\mathrm{Na}$ which tended to be related to the mean RZT but their

\section{Literature Cited}

Association of Official Analytical Chemists. 1990. Official methods of analysis. Assn. Off. Anal. Chem., Wash., D.C.

California Department of Food and Agriculture. 1997. California agricultural statistics 1997. Calif. Dept. Food Agr., Sacramento.

Cartujano-Escobar, F., L. Jankiewicz, V.M. Fernández-Orduña, and J. Mulato-Brito. 1985a. The development of the husk tomato plant (Physalis ixocarpa Brot.). I. Aerial vegetative parts. Acta Soc. Bot. Poland 54:327-338.

Cartujano-Escobar, F., L. Jankiewicz, V.M. Fernández-Orduña, and J. Mulato-Brito. 1985b. The development of the husk tomato plant (Physalis ixocarpa Brot.). II. Reproductive parts. Acta Soc. Bot. Poland 54:339-349.

Cooper, A.J. 1973. Root temperature and plant growth - A review. Commonwealth Agr. Bur., Slough, U.K.

Decoteau, D.R., M.J.Kasperbauer,D.D. Daniels, and P.G. Hunt. 1988. Plastic mulch color effects on reflected light and tomato plant growth. Scientia Hort. 34:169-175.

Díaz-Pérez, J.C. and K.D. Batal. 2002. Colored plastic film mulches affect tomato growth and yield via changes in root-zone temperature. J. Amer. Soc. Hort. Sci. 127:127-136.

Díaz-Pérez, J.C., D. Granberry, D. Bertrand, and D. Giddings. 2004. Tomato plant growth during establishment as affected by root zone temperature under colored mulches. Acta Hort. 631:119-124.

Díaz-Pérez, J.C. and H.R. Pappu. 2000. First report of Tomato spotted wilt virus infection of tomatillo in Georgia. Plant Dis. 84(10):1155.

Dodd, I.C., J. He, C.G.N. Turnbull, S.K. Lee, and C. Critchley. 2000. The influence of supra-optimal root-zone temperatures on growth and stomatal conductance in Capsicum annuum L. J. Expt. Bot. 51:239-248.

Freyre, R. and J.B. Loy. 2000. Evaluation and yield trials of tomatillo in New Hampshire. HortTechnology 10:374-377.

Kinet, J.M. and M.M. Peet. Tomato. In: Wien, J.C. (Ed.). The physiology of vegetable crops. CABI Publishing, London, pp. 207-258.

Lamont, Jr., WJ. 1993. Plastic mulches for production of vegetable crops. HortTechnology 3:35-39.

Liakatas, A., J.A. Clark, and J.L. Monteith. 1986. Measurements of the heat balance under plastic mulches. Agr. For. Meteorol. 36:227-239.

Martínez, M. 1954. Plantas útiles de la flora de México. Botas, Mexico.

Miller, D.E. 1986. Root systems in relation to stress tolerance. HortScience 21:963-970.

Montes-Hernández, S. and J.R. Aguirre-Rivera. 1994. Neglected crops: 1492 from a different Perspective, p. 117-122 In: J.E. HernándezBermejo and J. León (eds.). Plant production and protection. Ser. 26. FAO, Rome.

Moriconi, D.N., M.C. Rush, and H. Flores. 1990. Tomatillo: A potential vegetable crop for Louisiana, p. 407-413. In: J. Janick and J.E. Simon (eds.). Advances in new crops. Timber Press, Portland, Ore.

Pandey, K.K. 1957. Genetics of self-incompatibility in Physalis ixocarpa Brot.-Anew system. Amer. J. Bot. 44:879-887.

Paulsen, G.M. 1994. High temperature responses of crop plants, p. 365-389. In: K.J. Boote, J.M. Bennett, T.R. Sinclair, and G.M. Paulsen (eds.). Physiology and determination of crop yield. Amer. Soc. of Agron., Madison, Wis.

Quiros, C.F. 1984. Overview of the genetics and breeding of husk tomato. HortScience 19:872-874.

Sahagún de, B. 1956. Historia general de las cosas 


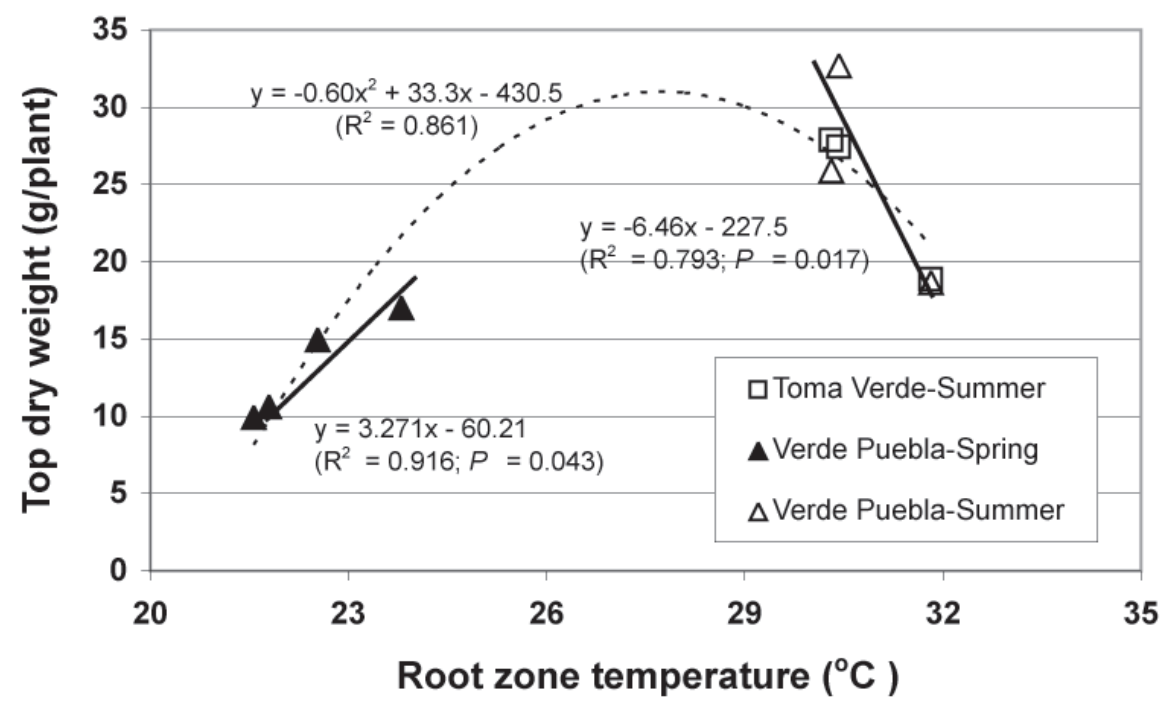

Fig. 6. Relationship of mean root zone temperature during the establishment period (first $28 \mathrm{~d}$ after transplanting) with the top dry weight of two tomatillo cultivars in the spring and summer seasons. Each symbol represents the mean top dry weight for a given mulch and tomatillo cultivar. Solid lines were fit by linear regression. The quadratic curve (dotted line) was constructed from the pooled data from both seasons.
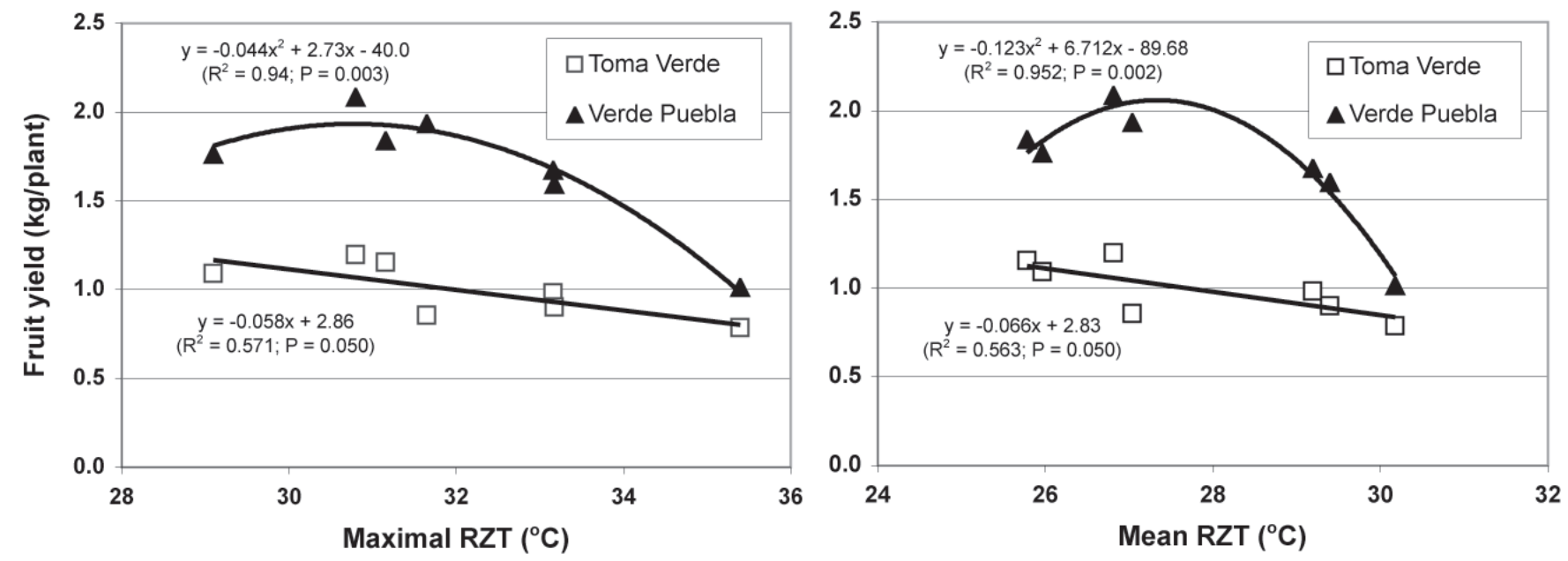

Fig. 7. Relationships of the average seasonal values of maximal and mean root-zone temperature (RZT) with the total fruit yield of two tomatillo cultivars. Graphs were constructed with data from the Spring and Summer seasons in 2000. Each symbol represents the mean fruit fresh weight for a given mulch and tomatillo cultivar. Solid lines were fit by linear regression.

Table 4. Mineral nutrient concentration in the soil of two tomatillo (Physallis ixocarpa Brot. ex Hornem.) cultivars grown on plastic film mulch during the summer season.

\begin{tabular}{|c|c|c|c|c|c|c|c|c|c|c|c|}
\hline \multirow[b]{2}{*}{ Treatment } & \multicolumn{11}{|c|}{ Nutrient concn $\left(\mu \mathrm{g} \cdot \mathrm{g}^{-1}\right)$} \\
\hline & $\mathrm{P}$ & $\mathrm{K}$ & $\mathrm{Ca}$ & $\mathrm{Mg}$ & $\mathrm{Mn}$ & $\mathrm{B}$ & $\mathrm{Fe}$ & $\mathrm{Zn}$ & Mo & $\mathrm{Cu}$ & $\mathrm{Na}$ \\
\hline \multicolumn{12}{|l|}{ Mulch } \\
\hline Bare & $42.8 \mathrm{~b}^{\mathrm{z}}$ & $22.0 \mathrm{a}$ & 327 & 15.2 & $11.6 \mathrm{~b}$ & $0.32 \mathrm{a}$ & $48 \mathrm{~b}$ & $5.8 \mathrm{a}$ & 0.15 & 0.81 & 16.3 \\
\hline Gray & $55.4 \mathrm{a}$ & $19.4 \mathrm{ab}$ & 340 & 14.5 & $14.2 \mathrm{a}$ & $0.23 \mathrm{~b}$ & $60 \mathrm{a}$ & $4.1 \mathrm{bc}$ & 0.13 & 0.64 & 16.7 \\
\hline Silver & $55.5 \mathrm{a}$ & $17.4 \mathrm{~b}$ & 323 & 15.2 & $14.0 \mathrm{a}$ & $0.22 \mathrm{~b}$ & $63 \mathrm{a}$ & $3.7 \mathrm{c}$ & 0.00 & 0.53 & 16.8 \\
\hline \multicolumn{12}{|l|}{ Cultivar } \\
\hline Toma Verde & 50.4 & 18.3 & 323 & 15.2 & 13.2 & 0.26 & 59 & 4.7 & 0.00 & 0.62 & 16.9 \\
\hline Mulch & $* *$ & NS & NS & NS & $*$ & $*$ & $* *$ & $* *$ & NS & NS & NS \\
\hline Cultivar & NS & NS & NS & NS & NS & NS & NS & NS & NS & NS & ** \\
\hline $\mathrm{M} \times \mathrm{C}$ & NS & NS & NS & NS & NS & * & * & NS & NS & NS & NS \\
\hline
\end{tabular}

${ }^{\mathrm{z}}$ Means separated within columns by Fisher's protected LSD test $(P \leq 0.05)$.

de la Nueva España. D.F., Porrúa, Mexico.

SAS Institute Inc. 2000. SAS / C OnlineDoc. Release

7.00. SAS Inst. Inc., Cary, N.C.

Schalk, J.M. and M.L. Robbins. 1987. Reflective mulches influence plant survival, production, and insect control in fall tomatoes. HortScience 22:30-32.

Smith, R., M. Jimenez, and M. Cantwell. 1999. To- matillo production in California. Univ. Calif. Div. Agr. Nat. Resour., Veg. Prod. Ser. Publ. 7246. Tarara, J.M. 2000. Microclimate modification with plastic mulch. HortScience 35:169-180. 
Table 5. Mineral nutrient concentration in tomatillo (Physallis ixocarpa Brot. ex Hornem.) leaves as affected by plastic film mulch and cultivar (summer).

\begin{tabular}{|c|c|c|c|c|c|c|c|c|c|c|c|c|c|}
\hline Treatment & $\begin{array}{c}\mathrm{N} \\
(\%)\end{array}$ & $\begin{array}{c}\mathrm{P} \\
(\%)\end{array}$ & $\begin{array}{c}\mathrm{K} \\
(\%)\end{array}$ & $\begin{array}{c}\mathrm{Ca} \\
(\%)\end{array}$ & $\begin{array}{l}\mathrm{Mg} \\
(\%)\end{array}$ & $\begin{array}{c}\mathrm{S} \\
(\%)\end{array}$ & $\begin{array}{c}\mathrm{Mn} \\
\left(\mu \mathrm{g} \cdot \mathrm{g}^{-1}\right)\end{array}$ & $\begin{array}{c}\mathrm{B} \\
\left(\mu \mathrm{g} \cdot \mathrm{g}^{-1}\right)\end{array}$ & $\begin{array}{c}\mathrm{Fe} \\
\left(\mu \mathrm{g} \cdot \mathrm{g}^{-1}\right)\end{array}$ & $\begin{array}{c}\mathrm{Zn} \\
\left(\mu \mathrm{g} \cdot \mathrm{g}^{-1}\right)\end{array}$ & $\begin{array}{c}\text { Mo } \\
\left(\mu g \cdot g^{-1}\right)\end{array}$ & $\begin{array}{c}\mathrm{Cu} \\
\left(\mu \mathrm{g} \cdot \mathrm{g}^{-1}\right)\end{array}$ & $\begin{array}{c}\mathrm{Na} \\
\left(\mu \mathrm{g} \cdot \mathrm{g}^{-1}\right)\end{array}$ \\
\hline \multicolumn{14}{|l|}{ Mulch } \\
\hline Bare & 3.3 & $0.60 \mathrm{a}^{\mathrm{z}}$ & $3.16 \mathrm{a}$ & 1.57 & 0.55 & 0.22 & $62 \mathrm{ab}$ & 30 & $150 \mathrm{ab}$ & 35 & $0.9 \mathrm{a}$ & 6 & 87 \\
\hline Black & 3.4 & $0.56 \mathrm{ab}$ & $2.98 \mathrm{ab}$ & 1.49 & 0.52 & 0.22 & $86 a$ & 31 & $135 \mathrm{~b}$ & 40 & $0.4 \mathrm{~b}$ & 6 & 97 \\
\hline Gray & 3.4 & $0.51 \mathrm{c}$ & $2.88 \mathrm{~b}$ & 1.50 & 0.55 & 0.22 & $84 \mathrm{a}$ & 30 & $141 \mathrm{ab}$ & 39 & $0.4 \mathrm{~b}$ & 6 & 99 \\
\hline Silver & 3.3 & $0.52 \mathrm{bc}$ & $2.96 \mathrm{ab}$ & 1.36 & 0.48 & 0.22 & $52 \mathrm{~b}$ & 31 & $161 \mathrm{a}$ & 38 & $0.4 \mathrm{~b}$ & 7 & 103 \\
\hline \multicolumn{14}{|l|}{ Cultivar } \\
\hline Toma Verde & 3.3 & 0.56 & 2.98 & 1.45 & 0.52 & 0.21 & 70 & $29 \mathrm{~b}$ & 146 & 39 & 0.5 & 6 & $85 \mathrm{~b}$ \\
\hline Verde Puebla & 3.4 & 0.53 & 3.00 & 1.53 & 0.53 & 0.23 & 72 & $32 \mathrm{a}$ & 147 & 37 & 0.5 & 6 & $108 \mathrm{a}$ \\
\hline \multicolumn{14}{|l|}{ Significance } \\
\hline Mulch & NS & $* *$ & NS & NS & NS & NS & $*$ & NS & * & NS & $* *$ & NS & NS \\
\hline Cultivar & NS & NS & NS & NS & NS & NS & NS & $* *$ & NS & NS & NS & NS & $* *$ \\
\hline $\mathrm{M} \times \mathrm{C}$ & NS & NS & NS & NS & NS & NS & NS & NS & NS & NS & NS & NS & NS \\
\hline
\end{tabular}

${ }^{2}$ Means separated within columns by Fisher's protected LSD test $(P \leq 0.05)$.

Tindall, J.A., R.B. Beverly, and D.E. Radcliffe. 1991. Mulch effect on soil properties and tomato growth using micro-irrigation. Agron. J. 83:1028-1034.

Tindall, J.A., H.A. Mills, and D.E. Radcliffe. 1990. The effect of root-zone temperature on nutrient uptake of tomato. J. Plant Nutr. 13:939-956.

Voorhees, W.B., R.R. Allmaras, and C.E. Johnson. 1981. Alleviating temperature stress, p. 217-266.
In: G.F. Arkin and H.M. Taylor (eds.). Modifying the root environment to reduce crop stress. Amer. Soc. of Agr. Eng. (St. Joseph, Mich.) Monogr. 4.

Waterfall, U.T. 1967. Physalis in Mexico, Central America and the West Indies. Rhodora 69:82-120.

Wien, H.C. 1990. Screening pepper cultivars for resistance to flower abscission: A comparison of techniques. HortScience 25:1634-1636.

Wien, H.C. and P.L. Minotti. 1987. Growth, yield, and nutrient uptake of transplanted fresh-market tomatoes as affected by plastic mulch and initial nitrogen rate. J Amer. Soc. Hort. Sci. 112:759-763.

Zobel, R.W. 1992. Soil environment constraints to root growth. Adv. Soil Sci. 19:27-51. 